\title{
The Principal's Leadership and Performance Result
}

\author{
* Annisya ${ }^{1}$, Zaka Hadikusuma Ramadan ${ }^{2}$ \\ 1,2 Universitas Islam Riau, Riau, Indonesia
}

\section{ART ICLE IN F O}

Article history:

Received March 03, 202

Revised April 08, 2021

Accepted April 30, 2021

Available online May 25, 2021

Kata Kunci:

Kepemimpinan Kepala Sekolah, Kinerja Guru

Keywords:

Principal Leadership, Teacher Performance

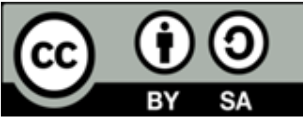

This is an open access article under the CC BY-SA license.

Copyright $(2021$ by Author. Published by Universitas Pendidikan Ganesha.

\begin{abstract}
A B S T RAK
Kinerja guru saat ini belum optimal, hal ini dapat dilihat dari rendahnya hasil belajar siswa. Salah satu faktor yang mempengaruhi keberhasilan kinerja guru adalah kepemimpinan kepala sekolah. Oleh sebab itu, dilakukan penelitian yang bertujuan untuk menganalisis kepemimpinan kepala sekolah dengan kinerja guru. Jenis penelitian yang dilakukan adalah deskriptif kualitatif. Data dikumpulkan dengan melakukan wawancara kepada kepala sekolah, guru sebanyak 3 staf sekolah dan siswa yang dipilih dari 2 siswa. Metode pengumpulan data yang digunakan adalah wawancara, observasi dan dokumentasi. Analisis data yang digunakan teknik analisis dari Miles dan Huberman. Hasil penelitian menyatakan bahwa kepemimpinan kepala sekolah yang baik dalam merencanakan, mengorganisasikan, mengarahkan, mengkoordinasi dan mengawasi akan mempengaruhi kinerja guru dalam menjalakan tugas merancang, melaksanakan pembelajaran, menilai pembelajaran, melakukan bimbingan dan melakukan tugas tambahan. Jadi, kepemimpinan kepala sekolah baik maka kinerja guru baik yang secara langsung mempengaruhi kualitas pembelajaran. Untuk meningkatakan kinerja guru, kepalasekolah haruslah melakukan program supervisi untuk membatu guru dalam menjalankan tugas.
\end{abstract}

\section{A B S T R A C T}

Teacher performance was currently not optimal; this can be seen from the low learning outcomes of students. one of the factors that influence the success of teacher performance was the Principal's leadership. Therefore, research was conducted that aimed to analyze the Principal's leadership with the teacher's performance. The type of research conducted was descriptive qualitative. The data was collected by interviewing head master, 3 school staff and selected students from 2 students. The data collection methods used are interviews, observations, and documentation. Analysis of the data used analysis techniques from Miles and Huberman. The results stated that good principal leadership in planning, organizing, deploying, coordinating, and supervising will affect teacher performance in performing designing tasks, carrying out learning, assessing learning, conducting guidance, and performing additional tasks. So, the Principal's leadership was good, then the teacher's performance was good, which directly affected the quality of learning. To improve teacher performance, the headmaster must conduct a supervised program to help teachers carried out their duties.

\section{INTRODUCTION}

The success of a school is inseparable from how the leadership of the Principal. The Principal's leadership is considered to play an essential role in the effectiveness and improvement of the school (Zheng et al., 2017) The headmaster's leadership is correlated with the Principal's leadership school's performance affecting the teacher's condition in performing their activities in the learning process (Player et al., 2017; Sodiah \& Nurhikmah, 2017) The Principal's decision to make policy for the school dramatically affects the school's achievements (Daniëls et al., 2019; Navaridas-Nalda et al., 2020) The improvement of school performance and the effectiveness of school staff's performance are strongly influenced by the skills of the Principal (Piaw et al., 2014) Many studies have been conducted related to the type of leadership of the Principal who stated that transformational leadership influences teacher performance changes (Arokiasamy et al., 2016) this improvement in teacher performance is due to satisfaction with the leadership of the Principal (Amin et al., 2013; Aydin et al., 2013) Qualified principal leadership will affect students' achievement (Coelli \& Green, 2012; Grissom et al., 2015) The change in the headmaster's leadership will affect students' learning achievement (Wills, 2016) The headmaster's 
leadership can increase teacher motivation (Kara \& Ertürk, 2015) teacher self-confidence (S. Liu et al., 2016) The explanation gives an idea of how the headmaster's leadership influences the school's achievements. Quality principal leadership will undoubtedly have an impact on the quality of education. To achieve this, the Principal must have competence, attitude, and good performance as well.

However, the current problems in the headmaster's leadership field still have to be developed concerning attitudes and competencies (Cohen, 2015) The Principal feels that they are in a higher position than teachers and staff, which is characterized by a command line and blames the teacher, affecting the teacher's performance (Wijania, 2017). The low performance of teachers and teachers' low performance is inseparable from the low contribution of the Principal in fostering teachers in the school (Koswara \& Rasto, 2016; Pramesti \& Muhyadi, 2018) This condition has an impact on learning outcomes. The current student learning outcomes can not be said to be successful due to the Principal's leadership because both directly and indirectly, the Principal's leadership affects the achievement of learning (S. Liu et al., 2016) The headmaster's leadership is always in the spotlight because all performance results must be accounted for. It is not uncommon for principals who cannot do their job correctly or otherwise have to accept the consequences such as being mutated. This will certainly greatly affect the leadership of a school experiencing a change of leadership, which will also affect teacher performance and school activities. So, the current leadership of the Principal can not be said to be good because this can be seen from the implementation of teachers who have not been optimal. If this is voiced, it will certainly have a less good influence on the quality of learning. Therefore, what can be used as a measure the success of the Principal in leading the school is the achievement of the school and the performance of teachers in the learning process.

The teacher's performance can be seen when he conducts teaching and learning interactions in the classroom, including his preparation in semester programs and teaching preparation (Karsiyem \& Wangid, 2015) Teacher performance is strongly related to ability and motivation in carrying out their duties properly and properly(Khoeriyah, 2015; Utami, 2017). Improved teacher performance will impact improving the quality of education (Andani et al., 2017; Leniwati \& Arafat, 2017) The success of teacher performance can be assessed from aspects of teacher performance in drawing up a learning plan, teacher performance in carrying out learning, teacher performance for evaluating student learning achievement, teacher performance in carrying out follow-up results of student learning achievement assessment (Kosman, 2019) Some studies that have been done have found that the factors that affect teacher performance are the leadership of the Principal (Erlangga et al., 2015; Gumilar \& Munzir, 2018; Jamma, 2016) teacher motivation in carrying out tasks (Setiyati, 2016) So, the teacher's success in completing the task and showing good performance is inseparable from how the headmaster's leadership.

This is one reason why research aimed at recognizing the leadership of the headmaster on teacher performance is performed. Knowing the condition of leadership will explain how the headmaster's skills in carrying out his managerial duties. A clear picture of how the headmaster's leadership in designing, organizing, deploying, and coordinating staff will be the basis for improving the headmaster's performance and teacher performance in managing the learning process. Research on teacher performance relationships and headmaster leadership has been conducted. From the results of the study, it was obtained that the headmaster's leadership was positive and significant to the teacher's performance (Cheng \& Szeto, 2016; Y. Liu \& Werblow, 2019; Ramadoni et al., 2016). Teacher performance can also be influenced by motivation (Sumarni, 2016) The better the teacher's confidence and the leadership style of the headmaster is also the performance shown by the teacher (Sulfemi, 2020) So it is essential to conduct research to analyze the leadership of the Principal with teacher performance.

\section{METHOD}

The type of research used in this study was qualitative descriptive research. The research procedure consists of, 1) determining the problem, the problem is based on the results of initial observations related to the leadership of the Principal; 2) determination of the title; 3) determine the focus of research, the focus of the research to be researched was how the leadership of the Principal and how the teacher's performance;3) the research stage, the research that will be conducted on the focus of research by using qualitative research;4) the stage of data collection, collecting data collecting techniques for interview data collection, observation and documentation; and 5) Analisis data, after all the data collected then conducted data analysis, researchers using Miles and Huberman data analysis namely data reduction, data presentation, and conclusion withdrawal. The data was collected from principals, teachers, and students, as well as education staff. The number of teachers and education personnel was 41 people with an education level of $1 \mathrm{~S} 2,35 \mathrm{~S} 1$ people, 1 person continuing to S2, 1 person continuing to S1 level, 2 high school students, and 1 elementary school graduate. The total number of students consisted of 157 
first grade students, 192-second grade students, 188 third-graders, 144 fourth graders, 156 fifth graders, and 6168 students..

Research data conducted with interviews, observations, and documentation studies. 1) Interviews, the purpose of the interview was conducted to obtain the required data, namely data on the Principal's leadership on teacher performance. Here the teachers interviewed were not authenticated, but all teachers have the opportunity to be interviewed and students. The interview will be conducted or started by asking permission to the Principal, interviewing him, the teacher, and the student, and after that meet the source to be interviewed. 2) Observation, observation here, observers will be actively involved in observing the object to be studied and the researcher himself who observed and experienced the object directly to be studied later. observations will be made directly to the Principal and teachers, and 3) Documentation, documents were done to collect attendance lists of teachers and principals or to support documentation in the form of images when researchers were conducting direct observations and interviews directly with the Principal or teacher. Researchers will use documentation as support or support for indicators of principal leadership, teacher performance and teacher competence, when conducting observations and interviews so that the expected data can be trusted. The method of data collection performed using the instrument, the instrument grid used, is described in table 1.

This study uses analysis techniques from Miles, and (Sugiyono, 2017) which consists of 1) Data Collection, 2) Data Reduction, 3) Data Display, and 4) Conclusion drawing/verification. The test on qualitative research includes trust, reliability, dependency, and certainty. Uji credibility qualitative research data was conducted by extension of observation, increased perseverance in research, triangulation, discussion with colleagues, negative case analysis, and member check. This transferability relates to the question of the extent to which the study results can be applied or used in other social contexts and situations. A dependability test was conducted by auditing the entire research process. Testing the affirmability meant trying the results of research associated with the operation performed. If the study results were a function of the process carried out, then the research has met the standards of affirmability.

Table 1. Instrument Grid

\begin{tabular}{|c|c|c|c|c|}
\hline Aspect & Indicator & $\begin{array}{l}\text { Inter } \\
\text { view }\end{array}$ & $\begin{array}{c}\text { Obser } \\
\text { vation }\end{array}$ & $\begin{array}{c}\text { Docume } \\
\text { nt }\end{array}$ \\
\hline $\begin{array}{l}\text { Princip } \\
\text { al's } \\
\text { Leader } \\
\text { ship }\end{array}$ & $\begin{array}{l}\text { Planning } \\
\text { a. Annual Program Planning. } \\
\text { b. How to plan the annual program. } \\
\text { c. Where and when to do annual program planning. } \\
\text { Organizing } \\
\text { a. Involve subordinates in school activities } \\
\text { b. Share precise work with subordinates } \\
\text { Directing } \\
\text { a. Directing subordinates by giving orders, instruction, } \\
\text { encouraging the spirit of work, enforcing discipline to } \\
\text { conform to the established direction or established guidelines } \\
\text { Coordinating } \\
\text { a. Provide opportunities for subordinates to argue } \\
\text { b. Accept every subordinate's opinion } \\
\text { c. Making decisions following mutual agreement } \\
\text { Controlling } \\
\text { a. Supervise any actions taken by subordinates } \\
\text { b. Review whether the actions performed are by the established } \\
\text { plan, instructions, commands, or other conditions. }\end{array}$ & $\sqrt{ }$ & $\sqrt{ }$ & $\sqrt{ }$ \\
\hline $\begin{array}{l}\text { Teache } \\
\text { rs' } \\
\text { Perfor } \\
\text { mance }\end{array}$ & $\begin{array}{l}\text { Lesson Planning } \\
\text { a. Make a lesson plan according to the curriculum, syllabus, and } \\
\text { pay attention to the characteristics of students } \\
\text { b. Plan effective learning } \\
\text { c. Choosing learning resources/learning media following the } \\
\text { materials and learning strategies } \\
\text { Conducting Lesson } \\
\text { a. Mastering learning materials } \\
\text { b. Implement practical approaches and learning strategies } \\
\text { c. Utilizing learning resources/media in learning }\end{array}$ & $\sqrt{ }$ & $\sqrt{ }$ & $\sqrt{ }$ \\
\hline
\end{tabular}




\begin{tabular}{|c|c|c|c|c|}
\hline Aspect & Indicator & $\begin{array}{l}\text { Inter } \\
\text { view }\end{array}$ & $\begin{array}{c}\text { Obser } \\
\text { vation }\end{array}$ & $\begin{array}{c}\text { Docume } \\
\text { nt }\end{array}$ \\
\hline & $\begin{array}{l}\text { d. Using the right and correct language in learning } \\
\text { Assessing } \\
\text { a. Assessing students' work in-class learning activities } \\
\text { b. Conducting assessments by the strategies, techniques, and } \\
\text { methods of evaluation or characteristics of students } \\
\text { c. Understand evaluation techniques or assessments, either test } \\
\text { or non-test. } \\
\text { Guiding and Training } \\
\text { a. Conducting guidance and training in the classroom } \\
\text { b. Conducting guidance and training outside the classroom } \\
\text { Giving Additional Work } \\
\text { a. Carry out additional tasks such as homeroom teacher, } \\
\text { extracurricular coach, picket teacher, etc.. }\end{array}$ & & & \\
\hline
\end{tabular}

\section{RESULT AND DISCUSSION}

The study results aimed at analyzing the headmaster's leadership on teacher performance obtained data related to the headmaster's leadership and teacher performance. Some research results related to the Principal's performance, namely, Principal Leadership told planning tasks. Based on the Principal's interview results, the Principal plans an annual program every year before the new school year. The principal plans a yearly program by studying the education calendar, which, among others, marked holidays, calculated the number of practical learning days, calculated the number of lesson hours, and distributed time allocation. The principal planned an annual program each year and the annual program of the Principal. The Principal had created the annual program based on the provisions and guidelines that have been set. So, the planning done by the Principal was in accordance with the rules and conditions in the field. This will undoubtedly affected the performance of the Principal. The Principal must plan all school activities outlined in the school's annual plan, which is then outlined in the school's annual program (Dwi \& Anggraeni, 2020) A good design will assist the Principal in achieving the vision and mission of the school. Considering the Principal was one of the very important factors that affect the school's success. The headmaster's leadership is correlated with the Principal's leadership school's performance involving the teacher's condition in performing their activities in the learning process (Player et al., 2017; Sodiah \& Nurhikmah, 2017) So that the design must be considered well and made in line with the vision and mission.

Second, the Principal's leadership was related to organizing tasks. Every activity carried out in the school always involves school staff, both teachers and educational personnel. The division of functions was adjusted to the ability or field pursued by the teacher. Also, the Principal will share and explain each teacher's duties clearly. Proof of teacher involvement was a work program created by the Principal; the principal's work program looks at teacher involvement and division of work for subordinates or teachers. Examples of activities conducted in schools involving teachers, every morning the Principal and teachers recite in the field alternately. The Principal divided the tasks to the teachers according to the teacher's ability clearly. All activities carried out in the school can not be done by the Principal himself. There needs to be cooperation between the Principal, teachers, students, and school committees. The Principal empowers others, encourages creativity and flexibility, improves collaborative planning, and shared decision-making to develop trust throughout the school environment (Vivianti \& Hadi, 2015) Good leadership in carrying out its leadership is where the organization wants to improve and develop individual's knowledge and ability (Kartini, 2019) The division of tasks that are in line with a person's ability now will certainly be very petrified of the achievement of educational objectives that are.

Third, the Principal's leadership was related to directing duties. The Principal directed educators and educational personnel by motivating teachers to obey the prevailing discipline and motivating educators and educational personnel to utilize ICT so that students can add knowledge and give reprimands to educators and academic personnel who were not disciplined and violate the discipline. In deploying educators and education personnel, principals by the applicable rules and educators and educational personnel follow the direction of the Principal following the instructions given. The Principal also enforces discipline to teachers who come to school late by asking the late teacher why it was too late and reprimanding the teacher to not be late to come to school again. This was evidenced by the existence of a supervision program that was made and done well. Giving motivation to teachers will make the work atmosphere more conducive. The explanation given by the boss will foster one's confidence in performing 
the tasks and responsibilities assigned (Kuswoyo et al., 2017) Leadership and motivation were very closely related because the success of a leader in mobilizing others in achieving a predetermined goal depends heavily on dignity and creates reason within each subordinate, colleague, or the superior leader himself (Titik Handayani, 2015; Inaray et al., 2016) Encouraging affection from the headmaster will encourage the teacher to complete the task (Wijania, 2017) So, the motivation given by the Principal is essential in building the teacher's confidence in achieving the work provided.

Fourth, the Principal's leadership relayed to coordinating duties. The Principal conducts deliberations or meetings with teachers in decision-making. The headmaster always allowed the teacher to argue. The Principal accepts the opinions expressed by the teacher and accommodates every opinion expressed by the teachers and the results of the desperation that will be taken based on the opinions that have been mutually agreed upon. A good leader is a leader who can listen to the views of others. The Principal succeed when they understand the school's existence as a complex and unique organization and can carry out the role of the Principal as someone who is given the responsibility to lead the school (Setiyati, 2016) Being a leader who believed that the organization was complex and unique, it was natural for decision-makers to listen to others. Listening to the opinions of others will have a positive influence on teachers. The Principal's leadership, who is consultative or willing to communicate two ways with the teacher, is a type of leadership that contributes to the teacher's performance (Erlangga et al., 2015).

Fifth, the Principal's leadership relayed to controlling duties. When giving assignments or in activities that were being carried out, the Principal supervises every action and action done by the teacher. The Principal led every action taken by the teacher, whether it was the teacher's duty in the learning activities or outside the learning activities. Supervising the teacher's performance in carrying out tasks both in the learning process and outside the learning process was the Principal's duty. Providing supervision over teacher performance will give an overview to the Principal to guide and direct teachers to realize educational objectives. By knowing the advantages and disadvantages of teachers will be the study material in conducting academic supervision. Academic supervision provides an overview of teachers' learning activities ranging from planning, implementation, and assessment activities (Karsiyem \& Wangid, 2015) Educational leadership in no way assesses the teacher's performance in managing the learning process alone but rather assists teachers in developing their professionalism skills (Khoeriyah, 2015; Sutoya \& Slamet, 2019). Academic supervision applied by the Principal was undoubtedly very effective because it can provide assistance, guidance, and guidance to teachers to work better in guiding students and improve their performance in enhancing learning in school.

Based on the Principal's results, the Principal's leadership can be said that Principal's leadership has been good. Such leadership will undoubtedly affect the performance of teachers. The Principal has the power or authority to direct all components of the school following his duties and responsibilities. Therefore, every Principal was required to professionally carry out his duties well considering the Principal was a planner who organizes all resources in the school and supervises and supervises all educational programs in the school to advance education. Teacher performance improvement can be pursued through the improvement of leadership behavior (Sumarni, 2016) The headmaster's good leadership style will also support the teacher's performance (Sulfemi, 2020) Principal leadership is key to a good school environment and achieving quality teaching and learning (Vivianti \& Hadi, 2015) This was in line with the results of research in which the leadership of a good principal will justify better performance. More details of teacher performance results were described as follows.

First, teacher performance in designing learning. Teachers already have LESSON PLAN, syllabus, absent students, assessment books, media/tools. But the lesson plan used temporarily was lesson plan remote learning (online method) was spoken of the current situation covid. The lesson plan made was by the syllabus made. The learning resources and media selected were under the material. However, some teachers did not use enjoyable learning media/resources. There were one or two students who did not attend seen from the teacher's absence. The grade book created by the teacher is incomplete, the teacher had not entered the student's grades. Second, the teacher's performance in carrying out learning. The learning process conducted by teachers has been effectively seen from the learning model and the media used was adjusted to the characteristics of elementary school children so that students seem enthusiastic in following the learning. However, there were still some teachers who have not used innovative learning models and media.

Third, Teacher performance in assessing learning outcomes. When carrying out learning, teachers certainly conduct an assessment of students' work in the classroom learning activities. As teachers used assessment techniques with various techniques, strategies, and assessment methods to assess students' work, teachers already understand the techniques of evaluation of tests and non-tests. Fourth, the teacher's performance in guiding and training students. Teachers in carrying out learning did guidance and exercises in the classroom and outside the classroom for students who need to be taught, 
but learning outside the classroom can not be done because the students only 2 hours in school and after that students go straight home. Fifth, the teacher's performance in carrying out additional tasks. Teachers have other tasks besides being teachers, such as being a homeroom teacher, extracurricular coach and picket teacher, etc. In carrying out additional tasks, teachers have done well and earnestly. So, it can be said that the teacher's performance has been good, but some teachers have not used the model or engaging learning media this was due to factors such as the availability of facilities and infrastructure during online learning and the power in using or applying technology.

So, teachers' performance seen from making the design, implementation, assessing, mentoring, and performing additional tasks can be said to be good. Even though some of the teachers still have performance that must be improved, especially in online learning. Teacher performance can be seen when he conducts teaching and learning interactions in the classroom, including his preparation in semester programs and teaching preparation (Karsiyem \& Wangid, 2015) Teacher performance is strongly related to ability and motivation in carrying out their duties properly and properly(Khoeriyah, 2015; Utami, 2017). Improved teacher performance will impact improving the quality of education (Andani et al., 2017; Leniwati \& Arafat, 2017) Even though it has been said that the teacher's performance has been good, but some teachers still do not have a good performance. To overcome this, the principal had prepared a supervised program. The supervised program is given to help teachers improve their professional skills to help students learn to be better than before (Tutik Handayani, 2018) Supervision is not just to provide leadership to schools but rather to provide stimulus, coordination, and continuous guidance of teachers individually and individually (Amanda (Amanda et al., 2017; Astuti, 2017)

The results of this study reinforce the results of previous research that states that qualified principal leadership will affect students' achievement (Coelli \& Green, 2012; Grissom et al., 2015) The change in the headmaster's leadership will affect students' learning achievement (Wills, 2016) The headmaster's administration can increase teacher motivation (Kara \& Ertürk, 2015) teacher selfconfidence (S. Liu et al., 2016) From the results of the study, it was obtained that the headmaster's leadership was positive and significant to the teacher's performance (Cheng \& Szeto, 2016; Y. Liu \& Werblow, 2019; Ramadoni et al., 2016). Teacher performance can also be influenced by motivation (Sumarni, 2016) The better the teacher's confidence and the leadership style of the headmaster is also the performance shown by the teacher (Sulfemi, 2020) So, the Principal's leadership and the teacher's performance were two things that cannot be separated. Good leadership will result in good teacher performance, which will certainly affect the learning outcomes and achievements of the school. The results of this study were obtained that there was still a need for a supervised program to improve teacher performance in completing tasks given both related to learning and not.

\section{CONCLUSION}

Good principal leadership in planning, organizing, deploying, coordinating, and supervising will affect teacher performance in designing, implementing learning, assessing learning, conducting guidance, and performing additional tasks. If the headmaster's leadership was good, then the teacher's performance was good, directly affecting the quality of learning. To improve teacher performance, the headmaster must conduct a supervised program to help teachers carry out their duties.

\section{REFERENCES}

Amanda, M. O., Salam, R., \& Saggaf, S. (2017). Pengaruh Supervisi Kepala Sekolah Terhadap Kinerja Guru Di SMK Negeri 1 Bungoro Kabupaten Pangkep. Prosiding Seminar Nasional Himpunan Sarjana Ilmu-Ilmu Sosial, 2, 149-154.

Amin, M., Shah, S., \& Tatlah, I. (2013). Impact of principals/directors' leadership styles on job satisfaction of the faculty members: Perceptions of the faculty members in a Public University of Punjab, Pakistan. Journal of Research and Reflections in Education, 7(2), 97-112.

Andani, Y., Yulianto, A., \& Murwatiningsih, M. (2017). Model Supervisi Klinis Berbasis Teknologi Informasi dan Komunikasi Untuk Menigkatkan Kinerja Guru Produktif di SMKN 1 Kota Bima. Educational Management, 6(2), 163-169.

Arokiasamy, A. R. A., Abdullah, A. G. K., Ahmad, M. Z. @ S., \& Ismail, A. (2016). Transformational Leadership of School Principals and Organizational Health of Primary School Teachers in Malaysia. Procedia Social and Behavioral Sciences, 229, 151-157. https://doi.org/10.1016/j.sbspro.2016.07.124.

Astuti, S. (2017). Supervisi Akademik Untuk Menigkatkan Kompetensi Guru Di Sd Laboratorium Uksw. Scholaria: Jurnal Pendidikan Dan 49. https: //doi.org/10.24246/j.scholaria.2017.v7.i1.p49-59.

Aydin, A., Sarier, Y., \& Uysal, S. (2013). The Effect of School Principals' Leadership Styles on Teachers' 
Organizational Commitment and Job Satisfaction. Journal Articles; Reports - Research, 13(2), 806811.

Cheng, A. Y. N., \& Szeto, E. (2016). Teacher leadership development and principal facilitation: Novice teachers' perspectives. Teaching and Teacher Education, 58, 140-148. https: //doi.org/10.1016/j.tate.2016.05.003.

Coelli, M., \& Green, D. A. (2012). Leadership effects: School principals and student outcomes. Economics of Education Review, 31(1), 92-109. https://doi.org/10.1016/j.econedurev.2011.09.001.

Cohen, E. (2015). Principal Leadership Styles and Teacher and Principal Attitudes, Concerns and Competencies regarding Inclusion. Procedia - Social and Behavioral Sciences, 186(2002), 758-764. https://doi.org/10.1016/j.sbspro.2015.04.105.

Daniëls, E., Hondeghem, A., \& Dochy, F. (2019). A review on leadership and leadership development in educational settings. Educational Research Review, 27(December 2018), 110-125. https://doi.org/10.1016/j.edurev.2019.02.003.

Dwi, Y., \& Anggraeni, N. (2020). “ Superman ” Meningkatkan Kemampuan Kepala Sekolah Dalam Menyusun Administrasi Sekolah Di Gugus 04. Jurnal Manajemen Pendidikan, 2(2), 71-90.

Erlangga, E., Sugiyo, \& Supriyo. (2015). Kepemimpinan Kepala Sekolah, Kompetensi Profesional Berpengaruh Terhadap Kinerja Guru Bkmelalui Motivasi Kerja. Jurnal Bimbingan Konseling (Semarang), 4(2), 72-78. https://doi.org/10.15294/jubk.v4i2.9847.

Grissom, J. A., Kalogrides, D., \& Loeb, S. (2015). Using Student Test Scores to Measure Principal Performance. Educational Evaluation and Policy Analysis, 37(1), 3-28. https://doi.org/10.3102/0162373714523831.

Gumilar, G. G., \& Munzir, T. (2018). Pengaruh Gaya Kepemimpinan Kepala Sekolah Terhadap Kinerja Guru Sma Global Indo-Asia Batam. Jurnal Dimensi, 7(2), 232-238. https://doi.org/10.33373/dms.v7i2.1710.

Handayani, Titik. (2015). Pengaruh Kepemimpinan Kepala Sekolah, Motivasi Guru, Dan Budaya Organisasi Terhadap Kinerja Guru Sma Negeri Wonosobo. Jurnal Akuntabilitas Manajemen Pendidikan, 3(2), 264-277. https://doi.org/10.21831/amp.v3i2.6342.

Handayani, Tutik. (2018). Peningkatan Kemampuan Kepala Madrasah dalam Menyusun Program Supervisi Pendidikan melalui Kelompok Kerja Kepala Madrasah (KKM) Berbasis Pendampingan di Madrasah Binaan. Jurnal Kependidikan, 6(1), 107-122. https://doi.org/10.24090/jk.v6i1.1693.

Inaray, J. C., Nelwan, O. S., \& Lengkong, V. P. K. (2016). Pengaruh Kepemimpinan Dan Motivasi Kerja Terhadap Kinerja Karyawan Pada Pt. Amanah Finance Di Manado. Jurnal Berkala Ilmiah Efisiensi, 16(2), 459-470.

Jamma, H. (2016). Hubungan Gaya Kepemimpinan Dan Kinerja Dengan Etos Kerja Guru Sekolah Dasar Di Kota Padang Panjang. Al-Fikrah: Jurnal Manajemen Pendidikan, 1(2), 149. https://doi.org/10.31958/jaf.v1i2.360.

Kara, S. B. K., \& Ertürk, A. (2015). Mental Models of the School Principals on “Leadership.” Procedia - Social and Behavioral Sciences, 174, 2145-2152. https://doi.org/10.1016/j.sbspro.2015.02.014.

Karsiyem, K., \& Wangid, M. N. (2015). Pelaksanaan Supervisi Akademik Dalam Peningkatan Kinerja Guru Sekolah Dasar Gugus Iii Sentolo Kulon Progo. Jurnal Akuntabilitas Manajemen Pendidikan, 3(2), 201-212. https://doi.org/10.21831/amp.v3i2.6337.

Kartini. (2019). Komitmen Kepemimpinan Kepala Sekolah Dalam Mengimplementasi Kebijakan Untuk Meningkatkan Mutu Pendidikan di SMP Negeri 3 Palopo. Jurnal Studi Guru Dan Pembelajaran, 2(2), 51-64. https://doi.org/10.30605/jsgp.2.2.2019.1364.

Khoeriyah, S. (2015). Pengaruh Supervisi Akademik Terhadap Kinerja Guru Smp It Yaspida Sukabumi. Ta'dibi, 5(2), 34-38. https://doi.org/http://dx.doi.org/10.30997/jtm.v4i2.344.

Kosman, K. (2019). Upaya Meningkatan Kinerja Guru Dalam Pembelajaran Melalui Supervisi Edukatif Kolaboratif Secara Periodik. Jurnal Educatio FKIP UNMA, 5(1), 37-43. https://doi.org/10.31949/educatio.v5i1.34.

Koswara, K., \& Rasto, R. (2016). Kompetensi Dan Kinerja Guru Berdasarkan Sertifikasi Profesi. Jurnal Pendidikan Manajemen Perkantoran, 1(1), 61. https://doi.org/10.17509/jpm.v1i1.3269.

Kuswoyo, D. D., Pramono, H., \& Achmad Rifai. (2017). Kontribusi Percaya Diri, Konsentrasi dan Motivasi terhadap Kinerja Wasit Persatuan Sepak Bola Seluruh Indonesia Provinsi Sumatera Selatan. Journal of Physical Education and Sports, 6(3), 241-247.

Leniwati, L., \& Arafat, Y. (2017). Implementasi Supervisi Akademik Kepala Sekolah Untuk Meningkatkan Kinerja Guru. JMKSP (Jurnal Manajemen, Kepemimpinan, Dan Supervisi Pendidikan), 2(1), 106-114. https://doi.org/10.31851/jmksp.v2i1.1158.

Liu, S., Hallinger, P., \& Feng, D. (2016). Supporting the professional learning of teachers in China: Does principal leadership make a difference? Teaching and Teacher Education, 59, 79-91. 
https: //doi.org/10.1016/j.tate.2016.05.023.

Liu, Y., \& Werblow, J. (2019). The operation of distributed leadership and the relationship with organizational commitment and job satisfaction of principals and teachers: A multi-level model and meta-analysis using the 2013 TALIS data. International Journal of Educational Research, 96(December 2018), 41-55. https: //doi.org/10.1016/j.ijer.2019.05.005.

Navaridas-Nalda, F., Clavel-San Emeterio, M., Fernández-Ortiz, R., \& Arias-Oliva, M. (2020). The strategic influence of school principal leadership in the digital transformation of schools. Computers in Human Behavior, 112(December 2019). https://doi.org/10.1016/j.chb.2020.106481.

Piaw, C. Y., Hee, T. F., Ismail, N. R., \& Ying, L. H. (2014). Factors of Leadership Skills of Secondary School Principals. Procedia - Social and Behavioral Sciences, 116, 5125-5129. https://doi.org/10.1016/j.sbspro.2014.01.1085.

Player, D., Youngs, P., Perrone, F., \& Grogan, E. (2017). How principal leadership and person-job fit are associated with teacher mobility and attrition. Teaching and Teacher Education, 67, 330-339. https://doi.org/10.1016/j.tate.2017.06.017.

Pramesti, D., \& Muhyadi. (2018). Faktor-faktor yang Mempengaruhi Kinerja Guru SMA. Harmoni Sosial, 5(1), 43-56.

Ramadoni, W., Kusmintardjo, \& Arifin, I. (2016). Kepemimpinan Kepala Sekolah Dalam Upaya Peningkatan Kinerja Guru (Studi Multi Kasus Di Paud Islam Sabilillah Dan Sdn Tanjungsari 1 Kabupaten Sidoarjo). Jurnal Pendidikan (Teori Dan Praktik), 1(8), 1500-1504. https://doi.org/http://dx.doi.org/10.17977/jp.v1i8.6620.

Setiyati, S. (2016). Pengaruh Kepemimpinan Kepala Sekolah Terhadap Motivasi Kerja dan Kinerja Guru. Ilmu Pendidikan: Jurnal Kajian Teori Dan Praktik Kependidikan, 1(2), 63-70. https://doi.org/10.17977/um027v1i22016p063.

Sodiah, S., \& Nurhikmah, E. (2017). Etika Kerja Kepala Sekolah Dalam Meningkatkan Kinerja Guru. Tadbir : Jurnal Studi Manajemen Pendidikan, 1(2), 163. https://doi.org/10.29240/jsmp.v1i2.294.

Sugiyono. (2017). Metode Penelitian Kualitatif. Bandung: Alfabeta.

Sulfemi, W. B. (2020). Pengaruh Rasa Percaya Diri Dan Gaya Kepemimpinan Kepala Sekolah Terhadap Kinerja Guru. Nidhomul Haq: Jurnal Manajemen Pendidikan Islam, 5(2), 157-179. https://doi.org/10.31538/ndh.v5i2.557.

Sumarni. (2016). Kontribusi Motivasi Berprestasi Dan Kepemimpinan Kepala Sekolah Terhadap Kinerja Guru Sma Negeri Di Kecamatan Koto Tangah Kota Padang. Economica, 5(1), 63-68. https://doi.org/10.22202/economica.2016.v5.i1.307.

Sutoya, S., \& Slamet. (2019). Pengaruh Supervisi Akademik Kepala Sekolah Terhadap Kinerja Guru. (Jurnal Manajemen, Kepemimpinan, Dan Supervisi Pendidikan, 4(2), 188-193. https://doi.org/http://dx.doi.org/10.31851/jmksp.v4i2.2908.

Utami, S. (2017). Penerapan Supervisi Klinis untuk Meningkatkan Kinerja Guru dalam Proses Belajar Mengajar Gugus IV Sanankulon. Briliant: Jurnal Riset Dan Konseptual, 2(3), 272. https://doi.org/10.28926/briliant.v2i3.70.

Vivianti, V., \& Hadi, S. (2015). Peran Kepala Smk Negeri Di Kota Yogyakarta Berdasarkan Persepsi Guru. Jurnal Pendidikan Vokasi, 5(3), 394. https://doi.org/10.21831/jpv.v5i3.6492.

Wijania, I. W. (2017). Kontribusi Kepemimpinan Pelayan Kepala Sekolah, Motivasi Kerja Dan Disiplin Kerja Terhadap Kinerja Guru. Jurnal Ilmiah Pendidikan Dan Pembelajaran, 1(4), 176-184.

Wills, G. (2016). Principal leadership changes and their consequences for school performance in South Africa. International Journal of Educational Development, 51, 108-124. https://doi.org/10.1016/j.ijedudev.2016.08.005.

Zheng, Q., Li, L., Chen, H., \& Loeb, S. (2017). What Aspects of Principal Leadership Are Most Highly Correlated With School Outcomes in China? Educational Administration Quarterly, 53(3), 409-447. https://doi.org/10.1177/0013161X17706152. 